\title{
Sistem Penjadwalan Pertandingan Pencak Silat Berbasis Algoritme Genetika
}

\author{
Ari Kusuma Wardana ${ }^{* 1}$, Sri Hartati ${ }^{2}$ \\ ${ }^{1}$ Program Studi S2 Ilmu Komputer FMIPA UGM, Yogyakarta, Indonesia \\ ${ }^{2}$ Departemen Ilmu Komputer dan Elektronika, FMIPA UGM, Yogyakarta, Indonesia \\ e-mail: *11 ari.kusuma.w@mail.ugm.ac.id,${ }^{2}$ shartati@ugm.ac.id
}

\begin{abstract}
Abstrak
Algoritme genetika merupakan algoritme yang cukup populer dan sering digunakan dalam banyak bidang, biasanya algoritme genetika digunakan untuk pencarian solusi dalam sebuah permasalahan-permasalahan yang kompleks. Penjadwalan pertandingan pencak silat merupakan sebuah penjadwalan yang sangat kompleks serta memerlukan banyak waktu untuk membuatnya. Penelitian ini bertujuan untuk menerapkan atau mengimplementasikan algoritme genetika sebagai algoritme yang dapat menyelesaikan masalah penjadwalan pertandingan pencak silat dan dapat memenuhi semua batasan kaku (hard constraint) yang telah ditentukan serta meminimalkan pelanggran terhadap batasan lunak (soft constraint).

Di dalam penelitian ini algoritme genetika berperan sebagai algoritme yang bertugas menyelesaikan permasalahan penjadwalan pertandingan pencak silat pada Pimda 02 Tapak Suci Bantul. Populasi yang dihasilkan oleh algoritme genetika merepresentasi alternatifalternatif solusi yang ditawarkan. Kromosom terbaik yang ada pada populasi merupakan representasi solusi jadwal pertandingan yang berupa urutan partai pertandingan yang sesuai dengan aturan-aturan dalam penjadwalan pertandingan pencak silat.

Penelitian ini menghasilkan nilai fitness tertingi yang pernah dicapai sebesar 1. Penelitian ini diharapkan dapat dimanfaatkan oleh para panitia pertandingan pencak silat dalam membuat sebuah jadwal dalam kejuaraan pecak silat.
\end{abstract}

Kata kunci-penjadwalan pertandingan, pencak silat, algoritme genetika

Genetic Algorithm is one of famous algorithm and often used in many sector. Usually genetic algoritm is used in solution searching about complex problems. Pencak silat macth scheduling is a complex scheduling and needs a lot of time to made it. Objective this research implements a genetic algorithm as an algorithm which can solve the problem of pencak silat macth scheduling and can satisfy all of hard constraint and minimize soft constraint.

In this research genetic algorithm roles as algorithm which solves pencak silat mach scheduling problems in Pimda 02 Tak Suci Bantul. Population which produced by genetic algorithm represents solution alternatives which offered. Best chromosome in a population represents macth scheduling solution. This solution is sequence of match partai based on rules of pencak silat match scheduling.

This research produces best fitness value ever is 1. This research is expected helping pencak silat match committes make a pencak silat schedule in pencak silat championship.

Keywords - match scheduling, pencak silat, genetic algorithm 


\section{PENDAHULUAN}

B Anyak penelitian yang mencoba menyelesaikan permasalahan yang berkaitan dengan masalah penjadwalan. Ada penelitian yang meneliti tentang penjadwalan pada sebuah universitas [1], meneliti tentang penjadwalan pada sebuah rumah sakit [2], dan ada yang meneliti tentang penjadwalan pada sebuah cabang olahraga [3]. Penelitian-penelitian tersebut memiliki fokus penelitian yang berbeda, penelitian [1] memiliki fokus penelitian merancang dan membuat sebuah aplikasi yang menggunakan algoritme genetika untuk menyelesaikan masalah penjadwalan pada sebuah universitas, peneltian [2] memiliki fokus penelitian mengkaji penerapan algoritme genetika dalam menyelesaikan permasalahan penjadwalan perawat. Penelitian penjadwalan pada sebuah cabang olahraga [3] memiliki fokus penelitian tentang penjadwalan pertandingan divisi satu liga Ice Hokey di Finlandia.

Baru-baru ini, penelitian tentang penjadwalan di cabang-cabang olahraga mulai dipelajari secara intensif, diantaranya penelitian tantang penjadwalan olahraga dilakukan di Liga Football Australia [4], Super 14 Rugby [5], liga Ice Hokey Finlandia [3], Kompetisi Olahraga [6]. Selain penelitian-penelitian dari beberapa cabang olahraga tersebut, ada salah satu cabang olahraga yang juga menarik untuk diteliti dari sisi penjadwalannya. Salah satu cabang olahraga tersebut adalah Pencak Silat. Penjadwalan pertandingan Pencak Silat menjadi menarik untuk diteliti karena dalam setiap event turnamen Pencak Silat pasti diikuti oleh banyak peserta dan mempertandingkan banyak partai. Sehingga apabila panitia pelaksana tidak cermat dalam mengatur jadwal pertandingan maka dapat menimbulkan kesalahan fatal yang dapat mengacaukan jalannya turnamen.

Pada prinsipnya setiap penyelenggaraan kejuaraan pencak silat Tapak Suci harus dikelola secara tertib dan profesional karena sangat rawan protes. Tuntutan bekerja secara profesional untuk mengeliminasi setiap potensi kesalahan melahirkan pemikiran untuk membuat sebuah sistem penjadwalan pertandingan pencak silat Tapak Suci yang terkomputerisasi dengan menggunakan metode dan algoritme yang sering digunakan dalam menyelesaikan masalah penjadwalan, salah satu metode dan algoritme tersebut adalah algoritme genetika.

Pada tahun 1975 [7], John Holland memperkenalkan algoritme genetika. John Holland bermaksud membuat komputer berkelakuan seperti apa yang alam lakukan, yaitu evolusi populasi dengan seleksi alam sehingga hanya individu-individu yang kuat yang bisa bertahan. Algoritme genetika [8], merupakan suatu pendekatan yang dapat digunakan untuk menyelesaikan multiple objective optimazation problem. Pada setiap generasi, kromosom dievaluasi [9] berdasarkan suatu fungsi evaluasi dan menghasilkan suatu nilai fitness yang dapat menunjukkan derajat ketangguhan suatu kromosom dalam beradaptasi terhadap masalah. Setelah beberapa generasi maka algoritme genetika akan konvergen pada kromosom terbaik, yang diharapkan kromosom terbaik tersebut merupakan solusi optimal.

Pada penelitian ini algoritme genetika digunakan untuk menyelesaikan permasalahan penjadwalan pertandingan pencak silat pada Pimda 02 Tapak Suci Bantul. Di mana kromosom yang dihasilkan merupakan representasi solusi dari penjadwalan peserta pertandingan yang berupa jadwal pertandingan dalam suatu kejuaraan pencak silat.

\section{METODE PENELITIAN}

\subsection{Lokasi Penelitian}

Penelitian dilakukan di Gedung Dakwah Kabupaten Bantul, saat kejuaraan MUSABA CUP I yang dilaksanakan tanggal 22, 23, 24 Januari 2016 oleh Pimda 02 Tapak Suci Bantul. 


\subsection{Pengumpulan Data}

Data-data yang diambil terdiri dari data para peserta, bagan pertandingan, dan langkahlangkah serta aturan-aturan yang digunakan untuk membuat jadwal pertandingan kejuaraan MUSABA CUP I.

\subsection{Memodelkan Algoritme Genetika}

Memodelkan sebuah permasalahan yang ingin diselesaikan agar bisa diselesaikan oleh algorima genetika.

\subsubsection{Pengkodeean Kromosom}

Pengkodean kromosom dalam penelitian ini adalah dengan menggunakan pengkodean nilai [10]. Setiap kromosom merupakan suatu barisan dari nilai-nilai, di mana nilai tersebut dapat berupa apa saja yang berhubungan dengan masalah. Kromosom dalam penelitian ini berisi kumpulan dari genotype, di mana di dalam setiap genotype tersebut berisi dua gen. Satu gen merepresentasikan satu peserta. Contoh pengkodean kromosom adalah seperti yang tertera pada gambar 1.

\begin{tabular}{|c|c|c|c|c|c|c|}
\hline & \multicolumn{2}{|c|}{$\mathrm{P}_{1}$} & $\ldots$ & $\ldots$ & $\ldots$ & $P_{n}$ \\
\hline Kromosom 1 & 2.17.P.0.13.6.2 & 2.18.P.1.13.4.2 & & & & \\
\hline
\end{tabular}

\section{Gambar 1 Pengkodean Kromosom}

Gambar 1 di atas menggambarkan bahwa kromosom tersebut terdiri dari kumpulan genotype $P_{1}$ sampai $P_{n}$. $P_{1}$ sampai $P_{n}$ merupakan jumlah partai pertandingan yang akan dijadwalkan bertanding di dalam jadwal kejuaran pertandingan pencak silat. Pada masingmasing genotype berisi dua buah gen. Dua buah gen dalam genotype merepresentasikan dua buah peserta yang siap untuk dipertandingakan.

Pengkodean kromosom pada penelitian ini menggunakan pengkodean nilai. Kelas peserta dikodekan dengan angka yang letaknya berada paling depan (nomor 2). Angka kedua setelah tanda titik pertama merupakan angka yang mengkodekan peserta (nomor 17 dan 18). Huruf yang letaknya setelah tanda titik kedua merupakan huruf yang mengkodekan apakah peserta atau peserta partai berikutnya (P untuk peserta dan D untuk peserta partai berikutnya).

Angka yang letaknya setelah tanda titik ketiga merupakan angka yang mengkodekan apakah peserta tersebut adalah peserta unggulan atau tidak (angka 1 untuk peserta yang diunggulkan (champion) dan 0 untuk peserta yang bukan peserta unggulan (bukan champion). Angka yang letaknya setelah tanda titik keempat merupakan angka yang mengkodekan umur peserta (angka 13 dan 14 menyatakan bahwa umur dari peserta 13 tahun dan 14 tahun).

Angka yang letaknya setelah tanda titik kelima merupakan angka yang mengkodekan asal dari perguruan peserta (angka 6 misalnya mewakili perguruan A dan angka 4 mewakili perguruan B). Angka yang letaknya setelah tanda titik keenam merupakan angka yang mengkodekan prefer arena dari peserta. Prefer arena disini maksudnya adalah peserta bisa mengusulkan bertanding pada arena tertentu (angka 2 mewakili arena 2).

\subsubsection{Menentukan Fungsi Fitness}

Fungsi objektif yang dicari pada penelitian ini adalah meminimalkan penalti yang dihasilkan oleh pelanggaran terhadap batasan lunak yang sudah ditentukan. Persamaan 1 merupakan fungsi objektif dari penelitian ini.

$$
f(g)=\frac{1}{\left(1+\sum P_{i} \mathrm{v}_{i}(g)\right)}
$$


Di mana $\mathrm{P} i$ adalah nilai penalti dari aturan ke $\mathrm{i}$, sedangkan $\mathrm{v}_{i}(g)$ bernilai 1 jika partai $g$ melanggar aturan i, dan bernilai 0 jika partai $g$ tidak melanggar aturan $\mathrm{i}$.

\subsubsection{Membangkitkan Populasi Awal}

Populasi awal dibangkitkan secara acak, di mana populasi ini merupakan kumpulan dari beberapa individu yang merupakan representasi dari solusi penjadwalan pertandingan. Saat membangkitkan populasi awal, kromosom-kromosom yang terbentuk harus memenuhi aturanaturan hard constraint.

\subsubsection{Mengevaluasi Populasi}

Cara melakukan evaluasi populasi adalah dengan menghitung nilai bobot masingmasing individu berdasarkan nilai fitness yang telah ditentukan sebelumya.

\subsubsection{Seleksi Orangtua}

Memilih individu terbaik dengan fitness tertinggi yang akan menjadi bagian dari populasi baru pada generasi selanjutnya. Untuk mendapatkan individu terbaik, langkah yang dilakukan adalah dengan menggunakan roullete wheel. Roullete wheel digunakan untuk mencari induk yang akan digunakan pada proses perkawinan silang (crossover).

\subsubsection{Perkawinan Silang}

Perkawinan silang (crossover) merupakan proses pertukaran gen-gen dari dua induk yang telah terpilih memalui proses roulette wheel. Metode crossover yang dipilih dalam penelitian ini adalah metode uniform crossover.

\subsubsection{Mutasi}

Tujuan dari mutasi adalah untuk menambah keragaman karakteristik genetik dari populasi. Mutasi sendiri diartikan sebagai suatu perubahan yang terjadi pada bahan genetik baik pada urutan gen maupun pada kromosom. Metode mutasi yang digunakan dalam penelitian ini adalah mutasi swap.

\subsubsection{Update Generasi}

Setelah populasi baru terbentuk, maka populasi lama akan digantikan dengan populasi baru tersebut. Pada penelitian ini metode yang digunakan untuk update populasi adalah metode generational model, yaitu suatu populasi lama berukuran $\mathrm{N}$ kromosom akan digantikan dengan $\mathrm{N}$ individu baru pada generasi berikutnya. Untuk menjaga kromosom terbaik tetap ada menggunakan elitisme.

\subsection{Implementasi}

Pada tahap ini dilakukan implementasi perangkat lunak sesuai dengan proses perancangan yang telah dilakukan sebelumnya. Implementasi perangkat lunak dilakukan dengan menggunakan bahasa pemrograman $P H P$, serta menggunakan MySQL untuk mengelola database yang ada di dalam sistem.

\subsection{Pengujian}

Pada tahap ini sistem yang telah dibuat kemudian diuji dengan menggunakan data-data yang berasal dari data MUSABA CUP I. Apabila jadwal yang terbentuk sudah memenuhi batasan kaku dan nilai dari batasan lunak sudah seminimal mungkin, maka jadwal pertandingan sudah bisa digunakan dan tidak perlu dilakukan evaluasi atau perbaikan. Sebaliknya, apabila jadwal yang terbentuk tidak sesuai dengan batasan kaku dan nilai batasan lunak belum minimal, maka perlu dilakukan evaluasi dan perbaikan. Dengan kata lain hasil (output) dari jadwal yang terbentuk dijadikan dasar apakah perlu membuat perbaikan-perbaikan atau tidak. 


\subsection{Evaluasi dan Perbaikan Kesalahan}

Tahap ini merupakan tahap untuk mengevaluasi dan memperbaiki kesalahan-kesalahan yang terjadi dalam perangkat lunak yang telah dibuat.

\section{HASIL DAN PEMBAHASAN}

Pembahasan pada penelitian tentang sistem penjadwalan pertandingan pencak silat berbasis algoritme genetika meliputi beberapa hal. Diantaranya adalah pembahasan tentang pengaruh paramater algoritme genetika terhadap nilai fitness dan pengaruh parameter algoritme genetika terhadap waktu yang dibutuhkan saat menjalankan proses algoritme genetika di dalam sistem. Selain itu juga membahas tentang perbandingan antara jadwal yang dihasilkan dari sistem dengan jadwal yang dihasilkan secara manual.

\subsection{Pengaruh Perubahan Parameter Genetika}

Perubahan dalam parameter genetika memiliki pengaruh di dalam penelitian ini. Adapun pengaruh dari perubahan tersebut adalah sebagai berikut ini :

1. Pengaruh perubahan parameter jumlah kromosom dalam satu populasi.

2. Pengaruh perubahan parameter probabilitas crossover.

3. Pengaruh perubahan parameter probabilitas mutasi.

4. Pengaruh perubahan parameter jumlah generasi yang dibangkitkan.

5. Pengaruh perubahan parameter elitisme.

\subsubsection{Pengaruh Perubahan Parameter Jumlah Kromosom}

Pada pembahasan ini dilakukan sebuah percobaan, di mana pada percobaan pertama jumlah kromosom yang dibangkitkan sebanyak 50 kromosom, menggunakan probabilitas crossover 0.5 , probabilitas mutasi 0.8 dan elitisme sebanyak 4 kromosom, serta jumlah generasi yang ingin dibangkitkan adalah sampai 500 generasi. Untuk percobaan berikutnya cukup menambahkan lima kromosom dari jumlah kromosom sebelumnya dan tetap menggunakan probabilitas crossover, probabilitas mutasi, elitisme dan jumlah generasi seperti pada percobaan pertama. Setelah melakukan 10 kali percobaan dengan jumlah kromosom yang berbeda diperoleh hasil bahwa nilai fitness terbaik yaitu sama. Nilai fitness maksimal berada pada angka 1 dan tidak ada penurunan nilai fitness disetiap percobaan tersebut.

Jumlah kromosom pada satu populasi mempengaruhi waktu berjalannya proses algoritme genetika di dalam sistem. Semakin banyak jumlah kromosom pada satu populasi maka semakin lama waktu yang dibutuhkan untuk menyelesaikan proses algoritme genetika di dalam sistem. Waktu tercepat diperoleh pada saat percobaan pertama, yaitu saat jumlah kromosom 50. Waktu yang dibutuhkan saat percobaan pertama yaitu 7 detik.

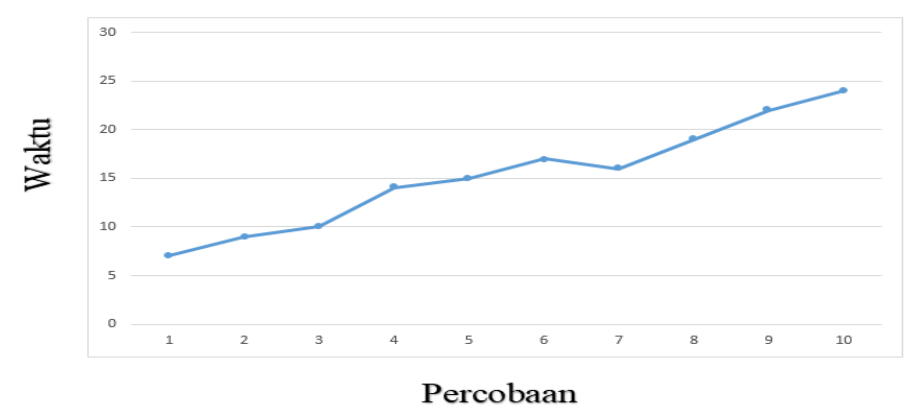

Gambar 2 Grafik Pengaruh Jumlah Kromosom

\subsubsection{Pengaruh Perubahan Parameter Probabilitas Crossover}

Pada pembahasan ini dilakukan sebuah percobaan, di mana pada percobaan pertama probabilitas crossover yang digunakan sebesar 0.1 , probabilitas mutasi adalah 0.8 , jumlah 
kromosom adalah 50, jumlah generasi adalah 500 dan elitisme adalah 4. Untuk percobaan berikutnya cukup menambahkan 0.1 dari probabilitas crossover sebelumnya dan tetap menggunakan probabilitas mutasi, jumlah kromosom, elitisme dan jumlah generasi seperti pada percobaan pertama. Setelah melakukan 10 kali percobaan dengan probabilitas crossover yang berbeda diperoleh hasil bahwa nilai fitness terbaik yaitu sama. Nilai fitness maksimal berada pada angka 1 dan tidak ada penurunan nilai fitness disetiap percobaan tersebut.

Nilai probabilitas crossover mempengaruhi waktu berjalannya proses algoritme genetika di dalam sistem. Semakin besar nilai probabilitas crossover yang digunakan maka semakin lama waktu yang dibutuhkan untuk menyelesaikan proses algoritme genetika di dalam sistem. Waktu tercepat diperoleh pada saat percobaan $1,2,3,4,5$ yaitu saat nilai probabilitas crossover $0.1,0.2,0.3,0.4$, dan 0.5 . Waktu yang dibutuhkan dari lima percobaan tersebut sama, yaitu 7 detik.

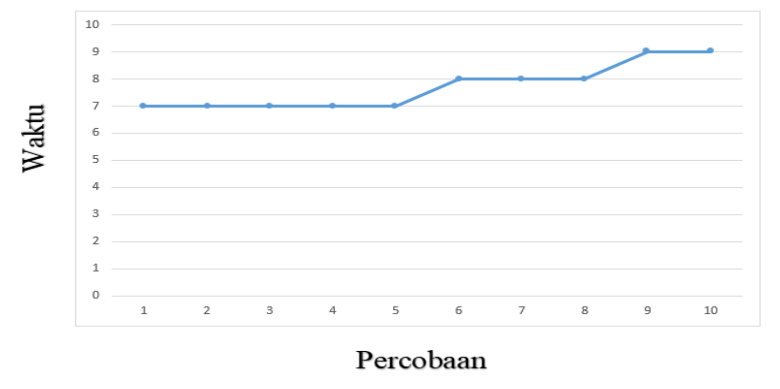

Gambar 3 Grafik Pengaruh Probabilitas Crossover

\subsubsection{Pengaruh Perubahan Parameter Probabilitas Mutasi}

Pada pembahasan ini dilakukan sebuah percobaan, di mana pada percobaan pertama probabilitas mutasi yang digunakan sebesar 0.1 , probabilitas crossover adalah 0.1 , jumlah kromosom adalah 50, jumlah generasi adalah 500 dan elitisme adalah 4. Untuk percobaan berikutnya cukup menambahkan 0.1 dari probabilitas mutasi sebelumnya dan tetap menggunakan probabilitas crossover, jumlah kromosom, elitisme dan jumlah generasi seperti pada percobaan pertama. Setelah melakukan 10 kali percobaan dengan probabilitas mutasi yang berbeda diperoleh hasil bahwa nilai fitness terbaik yaitu sama. Nilai fitness maksimal berada pada angka 1 dan tidak ada penurunan nilai fitness disetiap percobaan tersebut.

Nilai probabilitas mutasi mempengaruhi waktu berjalannya proses algoritme genetika di dalam sistem. Semakin besar nilai probabilitas mutasi yang digunakan maka semakin lama waktu yang dibutuhkan untuk menyelesaikan proses algoritme genetika di dalam sistem. Waktu tercepat diperoleh pada saat percobaan pertama yaitu saat nilai probabilitas mutasi 0.1 . Waktu yang dibutuhkan saat percobaan pertama yaitu 5 detik.

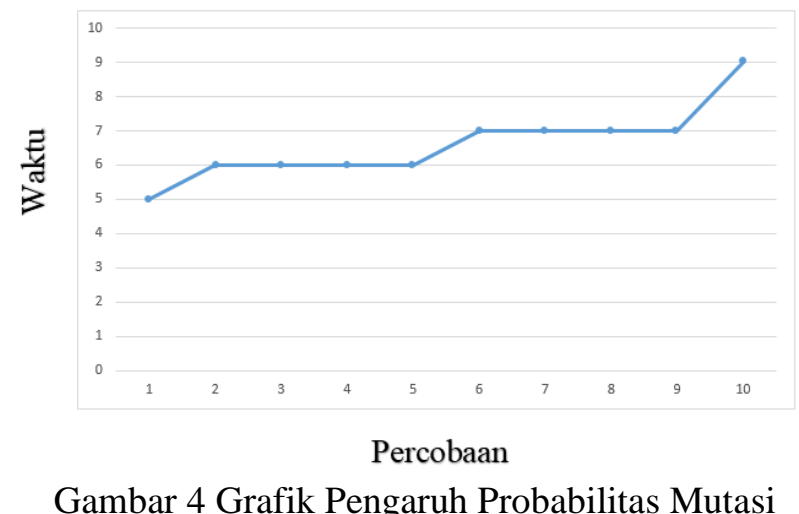

\subsubsection{Pengaruh Perubahan Parameter Jumlah Generasi}

Pada pembahasan ini dilakukan sebuah percobaan, di mana pada percobaan pertama jumlah generasi yang dibangkitkan yaitu 500, probabilitas mutasi sebesar 0.1, probabilitas 
crossover adalah 0.1 , jumlah kromosom adalah 50 dan elitisme adalah 4 . Untuk percobaan berikutnya cukup menambahkan 100 dari jumlah generasi sebelumnya dan tetap menggunakan probabilitas crossover, probabilitas mutasi, jumlah kromosom dan elitisme seperti pada percobaan pertama. Setelah melakukan 10 kali percobaan dengan jumlah generasi yang berbeda diperoleh hasil bahwa nilai fitness terbaik yaitu sama. Nilai fitness maksimal berada pada angka 1 dan tidak ada penurunan nilai fitness disetiap percobaan tersebut.

Jumlah generasi mempengaruhi waktu berjalannya proses algoritme genetika di dalam sistem. Semakin banyak jumlah generasi yang dibangkitkan maka semakin lama waktu yang dibutuhkan untuk menyelesaikan proses algoritme genetika di dalam sistem. Waktu tercepat diperoleh pada saat percobaan pertama yaitu saat jumlah generasi 500. Waktu yang dibutuhkan saat percobaan pertama yaitu 5 detik.

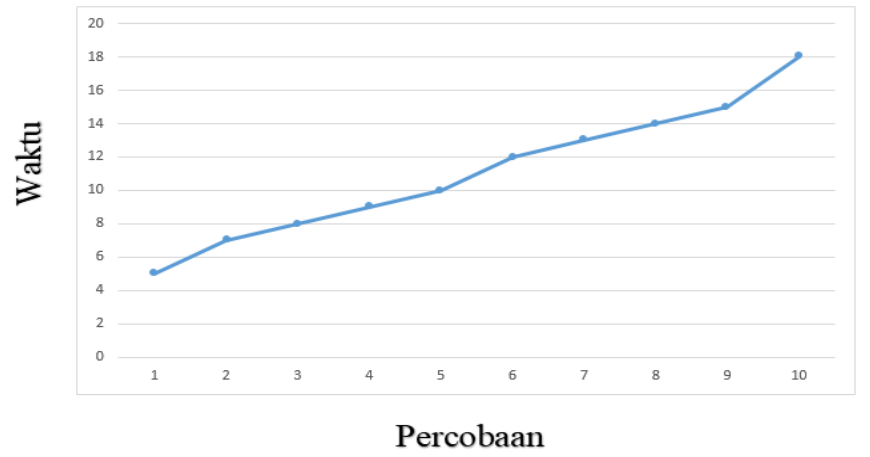

Gambar 5 Grafik Pengaruh Jumlah Generasi

\subsubsection{Pengaruh Perubahan Parameter Elitisme}

Pada pembahasan ini dilakukan sebuah percobaan, di mana pada percobaan pertama banyaknya elitisme yang diinginkan yaitu 1, probabilitas mutasi sebesar 0.1 , probabilitas crossover adalah 0.1, jumlah kromosom adalah 50 dan jumlah generasi adalah 500. Untuk percobaan berikutnya cukup menambahkan 1 dari jumlah elitisme sebelumnya dan tetap menggunakan probabilitas crossover, probabilitas mutasi, jumlah kromosom dan jumlah generasi seperti pada percobaan pertama. Setelah melakukan 10 kali percobaan dengan jumlah elitisme yang berbeda diperoleh hasil bahwa nilai fitness terbaik yaitu sama. Nilai fitness maksimal berada pada angka 1 dan tidak ada penurunan nilai fitness disetiap percobaan tersebut.

Jumlah elitisme mempengaruhi waktu berjalannya proses algoritme genetika di dalam sistem. Semakin banyak jumlah elitisme yang dibangkitkan maka semakin singkat waktu yang dibutuhkan untuk menyelesaikan proses algoritme genetika di dalam sistem. Waktu terlama diperoleh pada saat percobaan pertama yaitu saat jumlah elitisme 1 . Waktu yang dibutuhkan saat percobaan pertama yaitu 6 detik. Jumlah elitisme 1 memiliki waktu yang lebih lama 1 detik dibandingkan dengan jumlah elitisme yang lainnya.

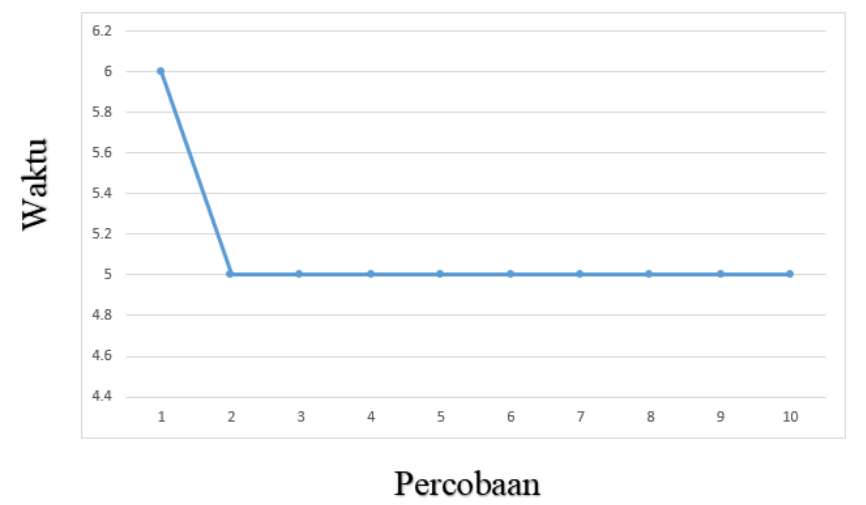

Gambar 6 Grafik Pengaruh Elitisme 


\subsection{Perbandingan Penjadwalan Manual dengan Sistem}

Untuk dapat mengetahui apakah hasil penjadwalan sistem sudah baik atau belum, maka perlu dilakukan sebuah pengujian hasil penjadwalan yang dihasilkan oleh sistem. Berikut ini adalah pembahasan mengenai penjadwalan yang dihasilkan oleh sistem :

\subsubsection{Kasus Tanpa Bye dan Voor Round}

Pada pembahasan ini dilakukan sebuah percobaan, di mana data yang akan dijadikan sebagai percobaan adalah data kelas Musaba Cup I yaitu kelas A putra SMP dan B putri SMP. Dimana Kelas A putra memiliki 4 peserta dan B putri 4 peserta. Parameter-parameter genetika dalam percobaan ini adalah : jumlah kromosom yang dibangkitkan yaitu 100, jumlah generasi 1000 , probabilitas crossover 0.5 , probabilitas mutasi 0.8 , dan elitisme 4 .

Dengan menggunakan parameter-parameter yang lebih spesifik seperti yang telah disebutkan maka salah satu dari efek dari parameter-parameter tersebut adalah akan membutuhkan waktu yang lebih lama saat melakukan pemrosesan di dalam sistem. Namun, di sisi lain keberhasilan dalam melakukan generate algoritme genetika akan semakin tinggi yaitu nilai fitness yang maksimal bisa didapatkan.

Berdasarkan pengujian sistem yang sudah dilakukan, urutan partai pertandingan yang dihasilkan sistem sama persis seperti yang dihasilkan oleh penjadwalan secara manual. Hal ini berarti bahwa jadwal yang dihasilkan oleh sistem tidak melanggar batasan kaku (hard constraint).

Nilai fitness yang dihasilkan oleh sistem yaitu 1. Dengan nilai fitness akhir 1 dalam percobaan ini, berarti batasan lunak berhasil diminimalkan. Nilai fitness 1 berhasil didapatkan karena data uji coba yang digunakan memungkinkan untuk memperoleh nilai fitness 1 .

Peningkatan kualitas jadwal pertandingan dapat terlihat dari sistem dapat mempertemukan peserta yang sama-sama diunggulkan (champion) pada partai 1. Sistem juga berhasil mempertemukan peserta senior yang memiliki umur lebih tua dari peserta lainnya (14 tahun) pada partai 4.

\subsubsection{Kasus Bye Round}

Pada pembahasan ini dilakukan sebuah percobaan, di mana data yang akan dijadikan sebagai percobaan adalah data kelas Musaba Cup I yaitu kelas Bebas putra SMP dan kelas B putri SMP. Dimana Kelas Bebas putra memiliki 12 peserta dan C putra 12 peserta. Parameterparameter genetika yang digunakan dalam percobaan ini sama persis dengan parameter yang digunakan pada kasus tanpa bye dan voor round.

Berdasarkan pengujian sistem yang sudah dilakukan, urutan partai pertandingan yang dihasilkan sistem sama persis seperti yang dihasilkan oleh penjadwalan secara manual. Hal ini berarti bahwa jadwal yang dihasilkan oleh sistem tidak melanggar batasan kaku (hard constraint).

Nilai fitness yang dihasilkan oleh sistem yaitu 0.5. Dengan nilai fitness akhir 0.5 dalam percobaan ini, berarti batasan lunak berhasil diminimalkan. Nilai fitness 1 tidak berhasil didapatkan karena data uji coba yang digunakan tidak memungkinkan untuk memperoleh nilai fitness 1. Partai 4 melanggar aturan soft constraint (beda prefer arena) sehingga nilai fitness tidak bisa bernilai 1 .

Peningkatan kualitas jadwal pertandingan dapat terlihat dari sistem dapat mempertemukan peserta yang sama-sama diunggulkan (champion) pada partai 10. Sistem juga berhasil mempertemukan peserta senior yang memiliki umur lebih tua dari peserta lainnya (14 tahun) pada partai 8 .

\subsubsection{Kasus Voor Round}

Pada pembahasan ini dilakukan sebuah percobaan, di mana data yang akan dijadikan sebagai percobaan adalah data kelas Musaba Cup I yaitu kelas A putri SMP dan kelas E putri SMP. Dimana Kelas A putri memiliki 5 peserta dan E putri 9 peserta. Parameter-parameter 
genetika yang digunakan dalam percobaan ini sama persis dengan parameter yang digunakan pada kasus tanpa bye dan voor round.

Berdasarkan pengujian sistem yang sudah dilakukan, urutan partai pertandingan yang dihasilkan sistem sama persis seperti yang dihasilkan oleh penjadwalan secara manual. Hal ini berarti bahwa jadwal yang dihasilkan oleh sistem tidak melanggar batasan kaku (hard constraint).

Nilai fitness yang dihasilkan oleh sistem yaitu 1. Dengan nilai fitness akhir 1 dalam percobaan ini, berarti batasan lunak berhasil diminimalkan. Nilai fitness 1 berhasil didapatkan karena data uji coba yang digunakan memungkinkan untuk memperoleh nilai fitness 1 .

Peningkatan kualitas jadwal pertandingan dapat terlihat dari sistem dapat mempertemukan peserta yang sama-sama diunggulkan (champion) pada partai 5. Sistem juga berhasil mempertemukan peserta senior yang memiliki umur lebih tua dari peserta lainnya (14 tahun) pada partai 2.

\subsubsection{Kasus Tiga Tipe}

Pada pembahasan ini dilakukan sebuah percobaan, di mana data yang akan dijadikan sebagai percobaan adalah data kelas Musaba Cup I yaitu kelas Musaba Cup I yaitu kelas A putri SMP, kelas A putra SMP dan kelas bebas putra SMP. Dimana Kelas A putri memiliki 5 peserta, kelas A putra memiliki 4 peserta, dan bebas putra memiliki 12 peserta. Parameter-parameter genetika yang digunakan dalam percobaan ini sama persis dengan parameter yang digunakan pada kasus tanpa bye dan voor round.

Berdasarkan pengujian sistem yang sudah dilakukan, urutan partai pertandingan yang dihasilkan sistem sama persis seperti yang dihasilkan oleh penjadwalan secara manual. Hal ini berarti bahwa jadwal yang dihasilkan oleh sistem tidak melanggar batasan kaku (hard constraint).

Nilai fitness yang dihasilkan oleh sistem yaitu 1. Dengan nilai fitness akhir 1 dalam percobaan ini, berarti batasan lunak berhasil diminimalkan. Nilai fitness 1 berhasil didapatkan karena data uji coba yang digunakan memungkinkan untuk memperoleh nilai fitness 1 .

Peningkatan kualitas jadwal pertandingan dapat terlihat dari sistem dapat mempertemukan peserta senior yang memiliki umur lebih tua dari peserta lainnya (14 tahun) pada partai 5, 7 dan 9 .

\section{KESIMPULAN}

Berdasarkan penelitian yang sudah dilakukan, maka dapat diperoleh kesimpulan sebagai berikut :

1. Algoritme genetika dapat membantu proses penjadwalan pertandingan pencak silat di PIMDA 02 Tapak Suci Bantul yang memenuhi batasan-batasan kaku dan meminimalkan batasan-batasan lunak yang telah ditentukan sebelumnya.

2. Nilai fitness terbaik yang pernah dicapai dalam penelitian ini ada dua (0.5 dan 1), yaitu ketika kasus tanpa bye dan voor round (nilai fitness 1), bye round (nilai fitness 0.5 ), voor round (nilai fitness 1) dan kasus tiga tipe (nilai fitness 1). Dengan nilai fitness tersebut jadwal pertandingan pencak silat bisa terbentuk dengan baik dan dapat digunakan.

3. Peningkatan kualitas penjadwalan yang dihasilkan oleh sistem dapat terlihat dengan sistem mampu mempertemukan peserta yang sama-sama diunggulkan (champion) dan mempertemukan peserta senior yang memiliki umur lebih tua dari peserta lainnya. 


\section{SARAN}

Berdasarkan pengujian yang sudah dilakukan, sistem pada penelitian ini masih banyak kekurangan sehingga perlu dikembangkan agar kinerja dari sistem lebih baik dari kinerja sistem yang sekarang. Saran yang dapat diberikan untuk penelitan selanjutnya adalah sebagai berikut :

1. Pada penelitian selanjutnya diharapkan metode algoritme genetika dapat menyelesaikan penjadwalan pertandingan pencak silat di kategori yang lain, seperti kategori tunggal, ganda dan beregu.

2. Pada penelitian selanjutnya diharapkan ada metode penjadwalan lain yang bisa menyelesaikan masalah penjadwalan pertandingan pencak silat selain algoritme genetika sehingga bisa dijadikan perbandingan metode mana yang lebih efektif untuk menyelesaikan masalah penjadwalan pertandingan pencak silat.

\section{UCAPAN TERIMA KASIH}

Penulis mengucapkan terima kasih kepada kedua orangtua yang telah memberi dukungan financial terhadap penelitian ini.

\section{DAFTAR PUSTAKA}

[1] Deng, X., Zhang, Y., Kang, B., Wu, J., Sun, X., dan Deng, Y., 2011, An Application of Genetic Algorithm for University Course Timetabling Problem, Chinese Control and Decision Conference (CCDC), IEEE Xplore, 978-1-4244-8738-7/11.

[2] Putra D. M. D. U., dan Subanar, 2012, Penerapan Algoritme Genetika Untuk Menyelesaikan Permasalahan Penjadwalan Perawat dengan Fuzzy Fitness Fuction, IJCCS, Vol.6, No.2, July 2012, pp. 11 22, ISSN: 1978-1520.

[3] Kyngäs, J., Nurmi, K., 2009, Scheduling the Finnish !st Division Ice Hockey League, Proceedings of the Twenty-Second International FLAIRS Conference.

[4] Barone, L., While, L., Hughes, P., Hingston, P., 2006, Fixture-scheduling for the Australian Football League using a Multi-Objective Evolutionary Algorithm, IEEE Congress on Evolutionary Computation, 0-7803-9487-9/06.

[5] While, L., dan Barone, L., 2007, Super 14 Rugby Fixture Scheduling Using a MultiObjective Evolutionary Algoritm. Proceedings of the 2007 IEEE Symposium on Computational Intelligence in Scheduling, 1-4244-0704-4/07.

[6] Guangdong, H., dan Qun, W., 2011, A hibrid ACO-GA on Sports Competition Scheduling, Ant Colony Optimization - Methods and Applications, Avi Ostfeld (Ed.), ISBN: 978-953-307-157-2.

[7] Negnevitsky, M., 2005, Artificial Intelligence: A Guide to Intelligent System 2nd Edition, Pearson Education Limited, England. ISBN 0-321-20466-2.

[8] Gen, M., dan Cheng, R., 2000, Genetic Algorithms and Engineering Optimization, John Wiley and Son, United States of America.

[9] Engelbrecht, A. P., 2002, Computational Intelligence An Introduction, John Wiley and Son, England.

[10] Obitko, M., 1998, X. Encoding, http://www.obitko.com/tutorials/geneticalgorithms/encoding.php, diakses tanggal 23 Juni 2016. 